\title{
Re-evaluating Syndicalist Opposition to the First World War
}

\section{Abstract}

It has been argued that support for the First World War by the important French syndicalist organisation, the Confédération Générale du Travail (CGT) has tended to obscure the fact that other national syndicalist organisations remained faithful to their professed workers' internationalism: on this basis syndicalists beyond France, more than any other ideological persuasion within the organised trade union movement in immediate pre-war and wartime Europe, can be seen to have constituted an authentic movement of opposition to the war in their refusal to subordinate class interests to those of the state, to endorse policies of 'defencism' of the 'national interest' and to abandon the rhetoric of class conflict. This article, which attempts to contribute to a much neglected comparative historiography of the international syndicalist movement, re-evaluates the syndicalist response across a broad geographical field of canvas (embracing France, Italy, Spain, Ireland, Britain and America) to reveal a rather more nuanced, ambiguous and uneven picture. While it highlights the distinctive nature of the syndicalist response compared with other labour movement trends, it also explores the important strategic and tactical limitations involved, including the dilemma of attempting to translate formal syndicalist ideological commitments against the war into practical measures of intervention, and the consequences of the syndicalists' subordination of the political question of the war to the industrial struggle. 
Keywords Syndicalism, trade unionism, First World War, internationalism

\section{Introduction}

During the first two decades of the twentieth century, amidst an extraordinary international upsurge in strike action, the ideas of revolutionary syndicalism connected and helped to produce mass workers' movements in a number of different countries across the world. An increasing number of syndicalist unions were to emerge as either existing unions were won over to syndicalist principles or new alternative revolutionary unions and organisations were formed by dissidents who broke away from their mainstream reformist adversaries. This international movement experienced its greatest vitality in the period immediately preceding and following the First World War, although the movement in Spain crested later.

Of course 'syndicalism' is necessarily only a very broad term for a number of related but rather different revolutionary union movements that flourished in a variety of forms. ${ }^{1}$ Although it was an international phenomenon that grew out of similar economic, social and political conditions, syndicalism manifested itself concretely in direct relation to national conditions and traditions, with each country producing its own specific version or versions of the movement which were far from uniform. Indeed the terms which they used themselves or had pinned on them varied, including: 
'revolutionary syndicalism' (France and Britain), 'industrial unionism' (America) and 'anarcho-syndicalism' (Spain and Italy). ${ }^{2}$ Nonetheless, arguably the colloquial description of such different movements as 'syndicalist' is both useful and justified because it draws attention to basic fundamental ideological and practical similarities between them (notwithstanding the specific strategic approaches and organisational forms adopted by individual movements), as reflected in the cross-fertilisation that took place between movements internationally. ${ }^{3}$

It was an international syndicalist project characterised by an underlying common philosophy of action. Parliamentary democracy and working for reforms through the state were rejected as dead ends. Instead of the social democratic conception of socialism introduced from above syndicalism was a movement committed to destroying capitalism through extra-parliamentary direct action and revolutionary industrial struggle from below. The principle of complete political independence was adopted in response to existing socialist and labour parties - all of whom were perceived to be corrupted with electoralism, reformism and bureaucracy. The traditional function of trade unions - struggling to better wages and working conditions through collective bargaining - was regarded as inadequate. Instead, syndicalists campaigned in favour of reconstructed revolutionary trade unions and believed the road to the emancipation of the working class lay through an intensification of the industrial struggle (involving boycotts, sabotage, strikes and solidarity action) eventually culminating in a revolutionary general strike that would lead to the overthrow of the 
capitalist system and its replacement by workers' control of industry and society. As the decisive agency of workers' action, revolutionary unionism had a double function - as an organ of class struggle against capitalism in the present and as an organ of economic and industrial administration after its overthrow in the hoped-for classless society of the future.

Also integral to syndicalist philosophy was an anti-patriotic, anti-militarist and anti-war stance in which they counter-posed workers' internationalism to the division between nations. In this respect, in an important contribution to our understanding of the wider trade union movement's response to the First World War, Wayne Thorpe has argued that European revolutionary syndicalist organisations viewed internationally, were unique in not supporting the imperialist ventures of their respective governments. Evidence is provided to suggest that support for the war by the important French syndicalist organisation, the Confédération Générale du Travail (CGT), has obscured the fact that five other national syndicalist organisations - in belligerent Germany and Italy, and in neutral Spain, Sweden and the Netherlands - remained faithful to their professed workers' internationalism. On this basis, it is argued, syndicalists beyond France, more than any other ideological persuasion within the organised trade union movement in immediate pre-war and wartime Europe, can be seen to have constituted an authentic movement of opposition to the war, refusing to subordinate class interests to those of the state, to endorse policies of 'defencism' of the 'national interest', or to abandon the rhetoric of class conflict. ${ }^{4}$ 
The substantive thrust of Thorpe's argument is undeniable. Indeed, it was not only the great majority of the official leadership of the trade union movement that rallied to the national cause. Practically all the leaders of the Second International (the collective voice of the world's socialist parties representing 3 million workers in 27 different parties), renounced their prior internationalist pledges and rushed to support their respective governments' war drive. This was despite repeated pledges that, in the event of war, social democratic parties would 'do all in their power to utilise the economic and political crisis created by the war to arouse the population and to hasten the downfall of capitalist class rule'. ${ }^{5}$ When in August 1914 the German Social Democratic Party (the main organisation of the Second International) voted in the Reichstag for war credits demanded by the government, its attitude was shared by virtually all other major parties of the International. Commitment to the reform of capitalism via the existing state led to social democracy's collapse into defence of national interests. By contrast, with its class-based revolutionary aspirations, the syndicalists generally took a strong position of opposition to the war on the basis that it was purely a conflict of capitalist interests quite unrelated to the interests of the working class; a conflict, however, in which the working class would be the major victim, sent into senseless slaughter to help line the pockets of the owners of industry.

Thorpe makes an important contribution by attempting to document the way in which within the organised trade union movement, measured internationally, an 
ideological variable may be said to have determined the response to war in 1914 - one which divided syndicalist trade unions from those of every other trend. In stressing this point, Thorpe has reinforced the broader historical interpretation of events portrayed by a number of contemporary anarcho-syndicalist activists who have endeavoured to keep alive the enduring relevance of the tradition. ${ }^{6}$ As one British author has commented: 'In contrast to the Marxists of the Second International, revolutionary syndicalism survived the outbreak of war with its revolutionary credentials intact - the CGT was alone in declaring its support for war' $^{\prime}{ }^{7}$

But Thorpe's contribution is also important for three other reasons. First, as the author of the classic monograph The Workers Themselves: Revolutionary Syndicalism and International Labour, 1913-1923, as well as a number of journal articles on the contribution of syndicalism to working class internationalism, Thorpe is one of the foremost historians of the movement, whose work unlike the vast majority of others has always concentrated on utilising a comparative dimension - and therefore is particularly worthy of serious assessment. Second, his specific analysis of syndicalist opposition to the First World War has provided a distinctive and detailed evidence-based academic analysis not previously available, and yet remarkably one which has also received negligible attention within historiography. Thirdly his analysis has rescued the often overlooked syndicalist contribution from right-wing and official Communist/Stalinist historians alike ${ }^{8}$ who have attempted for their own politically biased reasons to dismiss the significance of the movement (either as a means of downplaying the radicalism of 
workers' unrest on the one hand, or to elevate the general role of communist political parties in workers' struggles on the other).

However, notwithstanding the apparent distinctive nature of the syndicalist response to the First World War, Thorpe also acknowledged, although he did not emphasise, important qualifications to this stance in certain national contexts - notably the collapse into patriotism of the CGT in France (unquestionably the most important syndicalist organisation in Europe) and the pro-war 'interventionist' minority inside the Italian syndicalist movement. Moreover, Thorpe's study, which provided an essentially broad-brush stroke comparative overview, did not explore other ambiguities and limitations in syndicalist strategy and tactics more generally, in particular the tensions involved in attempting to translate formal syndicalist ideological commitments against the war into practical measures of intervention inside the working class movement, and the consequences of the syndicalists' subordination of political issues to the industrial struggle.

In an attempt to build on and extend Thorpe's pioneering contribution, so as to explore both the strengths as well as the limitations of the syndicalist stance towards the First World War, this article presents a much more disaggregated picture with a different and broader geographical field of canvas for study. Thus, as well as reevaluating (and providing new evidence on) the syndicalist response in countries such as France, Italy and Spain that Thorpe's work comments on, there is also consideration of 
other syndicalist or syndicalist-inclined movements in Ireland, Britain and America that he omitted. Apart from Italy and Spain, Thorpe's study looked at Germany, Sweden and the Netherlands. My different choice of countries can be justified on the basis of helping to illuminate both the significant variations in (subjective) syndicalist response to the war internationally (and beyond Europe), as well as the differential influence of (objective) national contexts, with the stark choice between workers' internationalism and national patriotism rather more acute in belligerent than in neutral states. In the process, the study reveals a rather more nuanced, ambiguous and uneven picture of the syndicalist movement to the one presented by Thorpe.

The research, which attempts to contribute to a much neglected comparative historiography of the international syndicalist movement, draws primarily on two sources: a very extensive range of existing secondary literature, including single-country studies on different labour and syndicalist movements as well as (where available) comparative overviews on the countries concerned; and a variety of primary sources, including the writings of syndicalists (and other contemporary commentators) contained in numerous newspapers, pamphlets, books and other archival material. ${ }^{9}$

To begin with the article looks at the opposition to war mounted by the syndicalists in Spain and Ireland, as well as their varying organisational fortunes amidst the relatively favourable context within which they operated. It then contrasts this experience with the internal schisms that afflicted the syndicalist movements in 
belligerent France and Italy, where large segments collapsed into nationalism. The article proceeds to make a further contrast with the movements in America and Britain, exploring the significance of the syndicalists' overall 'anti-political' stance for their opposition to war.

\section{Spain and Ireland: anti-war stance, broader beneficiaries}

In Spain undoubtedly the clearest and most consistent internationalist opposition towards the First World War within the organised labour movement came from the syndicalists in the Confederación Nacional de Trabajo (CNT), although this occurred within the relatively favourable context of the Spanish government remaining neutral in the conflict between the Central and Allied Powers. ${ }^{10}$ The Socialist Party gradually abandoned the pacifist internationalism that had previously led them to condemn Spain's colonial adventure in Morocco, and moved towards an overtly pro-Allied interventionist position. By contrast, the CNT professed to see only an equality of war guilt among the aggressor ruling classes, insisting it was of no concern to Spanish workers which side won, and demanding Spain's absolute neutrality in the war. Jóse Negre, the first secretary of the CNT, even went so far as to declare: 'Let Germany win, let France win, it is all the same to the workers, who will continue to be exploited and tyrannised just as before the war, and probably more than before'. ${ }^{11}$ "Whether one ship or a hundred ships be sunk", commented the confederation's paper Solidaridad Obrera, 
'we do not want war'. It would be far more sensible to use their weapons against 'more immediate enemies'. ${ }^{12}$

When the heavily anarcho-syndicalist inclined CNT discovered a number of outstanding international anarchist leaders (including Peter Kropotkin) had issued a Manifesto of the Sixteen in February 1916 declaring support for the Allied cause (which was backed by a small number of important Spanish anarchists), they angrily repudiated them. 'Rather than war - revolution!', cried the Ateneo Sindicalista of Barcelona in a manifesto written by Antonio Loredo and signed by hundreds of organisations. ${ }^{13}$ The only real dissenters from this anti-war orthodoxy were some militants in Galicia and Asturias. These 'minoritarians' were heatedly denounced by the majority of the Catalonian anarcho-syndicalists, and the violent anti-war polemics of Solidaridad Obrera (and the anarchist Tierra y Libertad) easily prevailed within the CNT. For example, on 1 April 1915 Solidaridad Obrera published a very significant statement against the war, entitled Manifesto Internacional. In August 1916 an editorial in the paper criticised the attitude of those in favour of intervening in the war in the name of liberty or democracy.

The present war is no different from any of the other wars that have bloodied the world; its causes and its ends are identical to those of previous wars. Industrial and commercial prevalence is what is being revealed here...

What is so regrettable is that, deceived by the tendentious campaign of the belligerent press, a host of sincere militants, instead of preparing for the revolutionary general strike, put their 
packsacks on their backs, thinking that they really were going to the trenches to defend Liberty and Justice. $^{14}$

Despite the fact the CNT (who had only just emerged from a period of illegality) were in disarray at the beginning of the war with barely 15,000 members, they were able to expand to 30,000 by the early part of 1915, and in March 1916 Solidaridad Obrera appeared as a daily. ${ }^{15}$ Their internationalism, albeit essentially propagandist in nature, undoubtedly proved attractive to a layer of the most militant workers, but the fact that Spain was not itself plunged into participation in the war also meant the hostile pressures on the CNT were much less severe than in belligerent countries. Moreover, a crucial contributory factor to the organisation's expanding membership (and of that of the socialist-led union confederation the Unión General de Trabajadores, UGT) was mounting working class opposition to food shortages and speculation arising from the war, which fused into underlying discontent with the political regime. The CNT's syndicalist commitment to destroying capitalism through direct action and revolutionary industrial struggle meant they were well placed to intervene to take advantage of the situation.

Ironically, despite traditional rivalry with the Socialist Party, now further embittered by their opposing stances on the war, rank-and-file pressure for cooperation between the CNT and the much larger UGT led eventually in July 1916 to the Pact of Saragossa. This resulted in a manifesto proclaiming agreement to work together 
to force the government to take action on the question of living costs and suggested a general strike as chief means of exerting pressure. Under the terms of the new accord, joint meetings were held in various cities and Spain's first nationally co-ordinated 24hour general strike took place in December 1916. Yet while the total number of strikers exceeded the combined membership of the two participating labour confederations, the protest made little impact on the government.

In 1917 political corruption, economic crisis, Catalan regionalism, dissatisfaction in the army, the international context - notably the inspiration of the February Russian revolution - and a resurgent workers' movement combined to produce a near revolutionary situation in Spain. A movement for liberalisation culminated in a national assembly of republican and Catalan deputies in Barcelona in July. The socialists, who were particularly keen to see the establishment of a republic as the first stage of the 'bourgeois revolution' prevailed on the CNT to organise jointly a revolutionary general strike. But the government, foreseeing the danger, provoked it before it was properly organised, and although the strike spread over large parts of Spain it was met with fierce repression, particularly in Barcelona where 12,000 troops were concentrated and a state of war proclaimed (leaving 70 dead, hundreds wounded and thousands arrested). This saw an early end to CGT-UGT collaboration, with the UGT viewing the debacle as proof of the incorrectness of the syndicalist general strike tactic, while the CNT viewed the socialists' inadequate tactics and the lack of support from bourgeois republicans as proof of the uselessness of collaboration with 'political' organisations. 
Even so, the CNT suffered no great setback from the outcome of the strike. In fact, news of the October 1917 Russian Revolution sparked off a three year period of unprecedented unrest across the country (Trienio Bolchevista, 'Three Bolshevik Years'), with a series of local general strikes and semi-insurrectionary movements which spectacularly helped to further boost CNT membership to 80,500 by the end of the war (and to 790,000 by December 1919 in the immediate post-war period, although by 1923 this had been reduced to a quarter of a million). ${ }^{16}$

Meanwhile, in Ireland on the outbreak of war, the main forces of the labour movement formally aligned themselves against imperialism, with the Irish Trades Union Congress declaring that a 'European war for aggrandisement of the capitalistic class has been declared' and demanding the retention of foodstuffs in Ireland. Similarly, Jim Larkin's syndicalist-inspired Irish Transport and General Workers Union (ITGWU) responded with a ferocious editorial in the Irish Worker: 'If England wants an empire let her hold the empire. What have we to do with her murderous, grasping, thieving work?...Remember by taking Britain's side in this unholy war you are giving up your claim that Ireland is a nation'. ${ }^{17}$ It was a war for the British Empire and Ireland's war was at home. Larkin's advice was to: 'Stop at home. Arm for Ireland. Fight for Ireland and no other land'. ${ }^{18}$ Even if support for such a stance was restricted to a tiny minority in the country as a whole, Larkin made anti-war speeches at every opportunity, the ITGWU paper Irish Worker was a mélange of anti-war propaganda and the union organised a number of small anti-war demonstrations in Dublin. ${ }^{19}$ 
However, with the outbreak of war occurring in the wake of the crushing defeat of the union in the Dublin strike and lockout of 1913, the ITGWU was much too weak to launch any industrial action in opposition to either the war or its effects. Instead, it looked to the republican Irish Volunteer Force, and made a determined attempt to capture it from moderate 'Home Rule' supporters by bitterly attacking those prepared to accept that the price of a proposed Irish parliament with some limited autonomy from British colonial control would have to be the partition of Ireland between north and south, insisting this outcome would merely consolidate and strengthen religious and sectarian divisions. When the Irish Volunteers' leader announced his support for Britain's war effort and called on his followers to enlist, Larkin asked the readers of the Irish Worker, 'Is there no man to provide a rope and a tree for this twentieth century Judas?'. ${ }^{20}$

Larkin left Ireland at the end of October 1914 for what was intended to be a short Transport Union fund-raising visit to America, although he was not to return until over eight years later. During his supposedly temporary absence the revolutionary socialist James Connolly, who had been actively involved with the Industrial Workers of the World in America and heavily influenced by syndicalist ideas, was appointed actinggeneral secretary of the union, taking over editorship of the Irish Worker and command of the union's own Citizen Army (armed defence force). He issued an appeal for the development of full-scale industrial unionism, for small unions catering for general 
labour to join together with the Transport Union in 'One Big Union' ${ }^{21}$ And Connolly advocated a general strike across Europe to stop the war. ${ }^{22}$

But despite the best efforts of Larkin, Connolly and their supporters, and the overall context of colonial subjugation, opposition to the war in Ireland was overwhelmed by a great surge of pro-British sentiment, such that by 1916 about half of the ITGWU's membership had enlisted in the British Army. ${ }^{23}$ The devastating Dublin defeat, combined with the impact of war, produced a collapse in union membership from over 30,000 to about 5,000 members by 1916 .

In response, Connolly sought another route to initiate a revolution, becoming one of the main instigators and leaders of the Easter Rising of 1916, an insurrection that he believed would link the cause of Irish freedom to the wider international battle against imperialism. ${ }^{24}$ Even though Ireland was a tiny country, Connolly thought it could play a particularly crucial role by striking a blow against the greatest empire of the day based in Britain, and in the process set off a chain reaction: 'Starting thus, Ireland may yet set the torch to a European conflagration that will not burn out until the last throne and last capitalist bond and debenture will be shrivelled on the funeral pyre of the last war lord' ${ }^{25}$ 
But despite being the leader of the ITGWU he did not openly campaign for the rising among the membership as a whole. Instead he embraced the politics of 'militarism' and exemplary action by a small but determined minority against British rule, as advocated by the radical Irish Republican Brotherhood's Military Council, with whom he now allied the tiny forces of the ITGWU's Citizen Army to become Dublin Commander of the combined forces. ${ }^{26}$ As a result, the 700 Volunteers and 120 Citizen Army members who seized control of the centre of Dublin and declared an independent Irish Republic did not enjoy popular support and were quickly overwhelmed by the British army. Connolly was one of sixteen leaders executed by a British firing squad afterwards. Lenin pointed out the tragedy was that the Irish rose 'prematurely, when the European revolt of the proletariat had not yet matured' ${ }^{27}$ Indeed they rose before war weariness had seriously gripped significant sections of the Irish population.

Yet following Connolly's death, the ITGWU, under the leadership of William O'Brien, was to experience a remarkable reversal in its fortunes, spectacularly increasing its membership to 12,000 by the autumn of 1917 and to over 40,000 by 1918 . On one level it was a recovery in workers' confidence to strike which provided the impetus for this revitalisation of the union - as the economic grievances of workers, reflected in a general wage demand movement throughout Ireland, produced a distinctly syndicalist dynamic. From 1917 onwards the spontaneous re-adoption of the Larkinite methods used in the Dublin lockout (of the sympathetic strike, refusal to touch 'tainted' goods or 
cross picket lines) attained increasing coherence as it was complemented by the practical implementation of Connolly's ideas of industrial unionism.

Meanwhile, paradoxically, despite the failure of the 1916 rising, the sheer ferocity of the British response had the effect of provoking widespread sympathy with the aim of ending British rule in Ireland. And the subsequent growing threat to introduce conscription in Ireland contributed to turning such sympathy into growing militant resistance. In April 1918 there was a huge upsurge of working class activity when the Irish Trades Union Congress organised a token but nevertheless successful one-day general strike on the conscription issue. Flushed with the success of the strike and inspired by news of revolution in Russia, there was a steady rise of industrial protest that not only brought another phenomenal spurt of growth for the ITGWU but also further encouraged the momentum of the national movement, eventually leading to Britain's humiliating retreat from most of Ireland. ${ }^{28}$

Thus, in both Spain and Ireland the syndicalist movements mounted opposition to the war, with Spain's neutrality and Ireland's colonial status providing the (relatively favourable) context within which this took place. Such a stance had real, albeit limited and varying, degrees of success in attracting support inside the working class movement. But in both countries the syndicalists' overall wartime growth in numbers and influence occurred primarily because they were able to be both beneficiaries of, and contributors to, the wartime industrial struggles and broader political issues 
(beyond the question of the war) that arose. By contrast, in France and Italy the situation was much more problematic.

\section{France and Italy: internal schisms, patriotism versus internationalism}

In France, in the face of the immediate threat of military defeat by Germany, the syndicalist movement's professed internationalism spectacularly collapsed. In fact, the CGT can only plausibly be seen as a revolutionary syndicalist body from its inception in 1902 until the outbreak of the war. There had always been other important forces inside the organisation apart from the anti-war revolutionary tendency, notably the pro-war reformists. With the onset of hostilities the latter gained the ascendancy and effectively became recruiting agents for the imperialist conflict. As a result of their early elaboration of syndicalist philosophy, their national prominence and their broader influence on the European syndicalist movement generally, the collapse of the French CGT was of major significance.

Even though the internationalist principles of the CGT were swept away overnight in August 1914 they had made important prior efforts to avert the coming war despite growing government repression. Thus, true to syndicalist doctrine the CGT had campaigned vigorously against patriotism. The bourgeoisie was viewed as relying upon the patriotic sentiments of the workers to distract them from their fundamental 
economic conflict with capital and to bind them more fully to the defence of bourgeois interests; the real division was not between nations but between the exploited and exploiters. The CGT's 1908 Marseille Congress had recalled the formula of the First International: 'The workers have no fatherland!' ${ }^{29}$ In place of national patriotism, they advocated international working class solidarity.

Such a viewpoint naturally led to a campaign of opposition to the threat of war. In 1908 the CGT had openly threatened that any declaration of war should be met with a revolutionary general strike, although significantly this resolution was careful to commit the confederation to no more than propaganda and to specify that the strike should be international. Nonetheless, in 1910, when the delegates of the Second International had agreed to turn over the responsibility of deciding anti-war tactics to a specially created bureau, 20,000 CGT supporters turned out at the congress of Toulouse to protest against war. ${ }^{30}$ In November 1912 a peace demonstration was staged in Paris, attracting some 60,000; and the unions called for a show of force in December, with a 24-hour general strike which repeated the call for the international working class movement to meet the outbreak of war with a revolutionary general strike. Although government repression deflected some of the strike's impact, about 80,000 workers were involved in these demonstrations. ${ }^{31}$

Despite such revolutionary internationalist sentiments and activities important counter-forces were also apparent. The reformists inside the CGT (organised in some of 
the larger unions and federations) were led by a powerful leadership, who represented a sizeable, albeit initially minority, body of opinion within the confederation. While they were committed to practical activism and strikes to win material improvements in workers' conditions, they rejected what they considered to be the more violent forms of direct action, such as sabotage and the general strike, particularly against the backcloth of the hostility of employers (who financed 'yellow' unions, imported 'blacklegs' and hired gunmen to intimidate strikers and pickets) and the Republican state machine (which utilised troops to ruthlessly crush the 1909 postal workers' and 1910 railway workers' strikes). Government concern at CGT anti-war campaigning was reflected in the spring and summer of 1913, by police raids of union headquarters and of the homes of hundreds of union members, with jail sentences imposed on a number of the principal syndicalist leaders (including Griffuelhes, Pouget, Yvetot).

In the context of such strike defeats and state repression, the incoming CGT leadership from 1912 onwards, under its new general secretary Leon Jouhaux, began to retreat from 'direct action' tactics towards a more pragmatic reformist approach. The growing war threat also encouraged the CGT leaders to a reluctant acceptance of the need to co-operate with reformist Socialist Party politicians. ${ }^{32}$

Once war was declared and conscription into the French armed forces announced, a wave of patriotism, a deep seated willingness to defend the Republic 
against external aggression, swept the French labour movement and carried almost the whole of the CGT (and the Socialist Party) before it. The CGT's independent stance collapsed and a number of its more militant leaders, as well as Jouhaux, actively participated in the war effort. The abandonment of internationalist principles by most socialist parties of the Second International, and their active collaboration with respective national governments, helped to open the floodgates. Yet the speed with which the most ardent French syndicalists (both reformist and revolutionary) became recruiting agents for the imperialist conflict was astonishing. For some it may have been fear of the consequences that led them to capitulate, with the prospect of illegality, persecution and prison; but for many the popular support for the war, a sense of patriotism and a genuine fear of the Germans appears to have been enough to send them to the front. ${ }^{33}$ An editorial in La Bataille syndicaliste argued that in the face of German militarism the democratic and republican traditions of France needed to be safeguarded. France, as Jouhaux repeatedly made clear, was fighting not a war of conquest but a war of defence against German imperialism and despotism; it was a war for civilisation, for progress and liberty against barbarism, a war of revolution and not reaction, truly in the 'revolutionary tradition' of $1792 .^{34}$

On 4 August the president of the Republic urged all citizens to commit themselves to a union sacrée ('sacred union') in defence of France, a union that the CGT (and Socialist Party) willingly agreed to uphold for the duration. This involved support for a no-strike pledge and a programme of compulsory arbitration, with the CGT serving 
on various mixed commissions and participating in several inter-allied conferences, and Jouhaux becoming a 'commissioner of the nation'. In the process most union members of military age were called up without resistance. From 350,000 adherents in 1913, CGT membership collapsed in the face of military mobilisation to a mere 49,000 dues-payers by 1915 , with the CGT becoming a 'skeletal' organisation. It was not until 1916-17 that membership began to revive to reach pre-war levels, and then doubled to just fewer than 600,000 by the end of the war. ${ }^{35}$

In spite of the crisis of French syndicalism there emerged a tiny internationalist and anti-war minority within the CGT. In December 1914 Pierre Monatte, the leader of the new generation of revolutionary syndicalists that had grown up around the paper $L a$ Vie Ouvrière, publicly resigned from the CGT executive committee in protest at the leadership's refusal to support a peace conference organised by the Scandinavian socialist parties. By the second year of the war, the opposition to the CGT had won over the powerful metal workers' union led by Alphonse Merrheim, who made speeches insisting 'their war is not our war'. ${ }^{36}$ A group of minoritaires formed into a Comité Défense Syndicaliste (CDS) and condemned the CGT majority for its collaboration with the government (and after 1917 for its alleged timidity in supporting the Russian Revolution). In September 1915 Merrheim, accompanied by Albert Bourderon, head of the coopers' union, attended the conference of anti-war socialists held at Zimmerwald in Switzerland. Ultimately this group, along with others on the revolutionary wing 
formed the nucleus of an internationalist and anti-war minority movement within the CGT, albeit marginalised during the early stages of the war. ${ }^{37}$

An immediate problem faced by those opposed to the war was how best to organise their dissent, a job made especially difficult due to the limited means at their disposal, the general dislocation of the labour movement, and the government's policy of where possible dispatching militants to the front. For example, when Monatte was called up into the army he faced the difficult decision of whether to disobey orders and face summary execution, a dilemma resolved only by the advice of his friends that such action would be a pointless exercise. In these almost impossible circumstances the capacity to sustain an anti-war campaign was limited. ${ }^{38}$

However, the catastrophic bloodletting of the years 1914-18 (during which over 1.3 million were killed), combined with the impact of the Russian Revolution, helped transform the situation more favourably during the last eighteen months of the war. Widespread army mutinies in May-June 1917 threatened the whole front with collapse. In September of that year the socialists, under rising pressure from below, withdrew from the Cabinet, and by July 1918 the previous 'minority' assumed control of the Socialist Party on the platform of a negotiated peace. 
Above all the strike wave of 1917-18 suggested the union sacrée consensus wore thin. Deteriorating working conditions, rising prices, profiteering and war weariness, all combined to reduce morale and encouraged growing numbers of workers to lend an ear to 'pacifist and Bolshevik' doctrines. In May-June 1918 there was a 200,000-strong metalworkers' strike, in which CDS militants played a key role channelling beyond bread-and-butter issues into an anti-war protest, although their influence was defused by the arrest of strike leaders and transfer of a few hundred mobilisés to the trenches. ${ }^{39}$ The immediate post-war years led to an increasing polarisation within the CGT between a reformist majority and a revolutionary minority, with the latter receiving a marked accession of strength from the Russian Revolution and the dangerously high social tensions that the war had generated. The internationalists split away to form the Confédération générale du travail (CGTU), a body which eventually became allied to communism.

In Italy, the outbreak of war also created turmoil (albeit on a much less significant scale than in France) within the 100,000-strong Unione Sindacale Italiana (USI), the largest syndicalist organisation outside of France. The Italian government, which had been in alliance with Germany and Austria-Hungary, had initially declared its neutrality. But after ten months Italy finally entered the war in May 1915, joining the Anglo-French-Russian alliance. It was a deeply unpopular decision that was opposed by parliament, the Catholic Church, the Socialist Party and its trade union confederation. The Socialists became the largest political movement in a belligerent state to refuse to 
endorse the national war effort. As part of this process, the USI also immediately avowed opposition to war with its central committee urging on 8 August 1914 that if the government abandoned its neutrality all workers should respond with an insurrectionary general strike. ${ }^{40}$

But although the bulk of the USI remained firm in their anti-militarist and internationalist stance, a number of syndicalist leaders, including Alceste DeAmbris, Tullio Masoitto and Michele Bianchi, decided to support republican France against the absolute monarchies of Germany and Austria and to call for Italian intervention on the side of the Allied Powers. ${ }^{41}$ Such figures, influenced by the republican nationalist tradition of Mazzini and the Freemasons, had witnessed the French CGT support the union sacrée and concluded that if their parent syndicalist organisation was in favour of protecting 'democracy" against the encroachment of the 'Hun', how could the Italian syndicalists do anything but follow their lead? ${ }^{42}$ DeAmbris, the fabled syndicalist leader, threw out the challenge: 'Friends, I ask you a question: What will we do when western civilisation is threatened by the suffocating imperialism of Germany and only our intervention can save it? I leave the answer to you'. ${ }^{43}$ He said the greatest menace to the revolutionary cause was not a war but rather the threat of a German victory. Such a victory, he felt, would destroy the proletarian movement and leave the workers in the clutches of German exploiters. ${ }^{44}$ Thus, the pro-war 'interventionists' asserted that while the syndicalists were anti-militarist they were not pacifist and the war would provide 
the opportunity for a revolution that would destroy the liberal political system and the monarchy. ${ }^{45}$

By contrast, the anarchist wing of the Italian syndicalist movement, led by Armando Borghi, demanded that the USI adhere to its internationalism. For Borghi there was no compromise with pacifism, it meant a total anti-war stance without regard for the Italian nation or any other nation. And in September 1914 the USI executive voted to expel DeAmbris and his followers. Even so the Parma Chamber of Labour, the largest section of the USI, voted to follow them on the path of intervention, with the Rome and Genoa Chambers of Labour (in which syndicalists were prominent) and the Maritime Union (an independent union) quickly joining them. And the Unione Sindacale Milanese, (the fourth largest section of the USI), also broke with the Milan Chamber of Labour and voted to back the interventionists. After this demonstration of support, DeAmbris and his followers seized control of the official records, financial statements and membership lists of the USI, and quickly converted L'Internazionale, the principal newspaper of the Italian syndicalist movement, into a pro-interventionist organ. ${ }^{46}$ Overall, they succeeded in taking almost one-third of the USI's membership, some 30,000 out of 100,000 . Whilst the group was too small to be effective on a national scale, it was large enough to greatly limit the effectiveness of the USI, even though the bulk of Italian syndicalists confirmed their anti-militarism and internationalism. 
In response to the interventionists, the USI executive selected Bologna as the union's new headquarters and appointed Borghi as secretary general, with Borghi attempting to rebuild the Unione by launching an anti-war propaganda offensive via a new official journal launched in the spring of 1915, the internationalist Guerra di Classe. Nonetheless, Edmondo Rossoni, a long time syndicalist who had participated in the 1908 Parma general strike, wrote from the United States to express his support for DeAmbris, ${ }^{47}$ and the editor of the Socialist Party's daily paper (L'Avanti!), Benito Mussolini, also began to write in favour of intervention. DeAmbris proceeded to establish hard-line groups, labelled Fasci rivoluzionari d'azione (Fasci), which increasingly violently attacked anti-war demonstrations. Meanwhile, when Borghi rejected a government's statement that impending Italian participation in the war should end the class struggle he was jailed for anti-patriotic remarks and later placed under house arrest. The combination of such interventionist attacks and government repression forced the USI to move its headquarters once again, this time to Piacenza, with their support dwindling as they battled for the next six months in an effort to keep Italy out of the war.

Borghi's attempt to rebuild the USI was further compounded by the political division that existed inside the Italian labour movement more generally. Two days before Italy entered the war Enrico Melabandri wrote a long article in Guerra di Classe, condemning the idea of unity with the Socialist Party because the latter's pacifism did not have a revolutionary aim and would result in nothing more than support for the 
existing state structure. ${ }^{48}$ Both the Socialist Party and its union confederation had declared themselves to be neutralist, adopting the formula of 'né aderire, né sabotare' refusing to either support the war or sabotage it (for fear disruption would only aid the enemy's ruling class). As a result they refused to work directly with the USI, but likewise the USI was not prepared to work with the Socialist Party, even after the latter had threatened to call a general strike if Italy did not remain neutral. The USI could not accept the fact that the Socialist Party would have political control in calling such protest action, since this would amount to a repudiation of their past stance against reformism. Thus, almost from the war's inception, the USI found itself shut off from the main segment of the neutralist movement. Such isolation inevitably weakened its position, already undermined by the internal split with the interventionists. ${ }^{49}$

However, while the internal schism was a crucial factor in the decline of USI membership in 1915-16, the war itself was to prove more decisive in affecting the syndicalists' longer-term fortunes. To increase production during the war years the government mobilised the Italian working class en masse, with strikes and agitation forbidden, under the threat of severe punishment; but it also established tripartite industrial commissions to settle industrial disputes on which the socialist-led union confederation was invited to elect representatives, thereby enhancing the latter's role and helping to lure thousands of workers away from the USI. What activity the Unione undertook tended initially to focus more on its own internal structures, such as mounting opposition to the pro-interventionist Parma Chamber of Labour, than with 
encouraging workers to fight for immediate improvements in wages and conditions. But if like other syndicalist organisations, the total membership of the USI declined considerably under the initial impact of the war, the organisation could still claim 48,000 members by the end of $1917 .^{50}$

As the war progressed it squeezed the Italian economy hard, leading to bread shortages. Strikes broke out over wages, there were large anti-war demonstrations, and in August 1917 a spontaneous insurrectionary general strike erupted in Turin inspired by news of the February revolution in Russia. Barricades were thrown up in working class quarters of the city, with USI activists and anarchists helping to organise defence against attack from government troops. The rising lasted four days before being crushed, with 50 workers killed, and several hundred wounded and arrested. And then in February 1918 Borghi and other leaders of the USI met with leading left-wing members of the Socialist Party (including Serrati) who rejected the official neutralist position, and agreed to jointly advocate direct action against the war effort. They envisaged the establishment of local anti-war organisations that would campaign to convince soldiers that continued fighting was senseless; and a plan was developed to seize arms from the munitions depots amidst simultaneous strikes in all armaments factories across northern Italy. But the government, informed of the plot, quickly moved to check the anti-war group, and imprisoned Borghi for attempting to foment revolution. 
Despite these apparent setbacks the economic strain of the war in Italy reached its height in 1918. As the cost of living increased and purchasing power plummeted, more and more workers responded by beginning to organise to defend themselves. For many the message of the Bolshevik revolution - immediate peace - appeared to offer the most compelling solution, and following the October revolution some 20,000 workers joined the USI, drawn in part by Borghi's message that the Italians should 'Do as they did in Russia'. As a result, in the final phase of the war and the immediate post-war period the USI expanded rapidly; by the end of 1919 it had enrolled 305,000 members and was 300 per cent larger in 1919 than it had been in 1914 (although the socialist union confederation exceeded this rate of expansion). ${ }^{51}$

The aftermath of war further polarised politics in Italy. On the one hand, workers' revolutionary militancy exploded in the "Bienno Rosso" ("Two Red Years") of 1919 and 1920, when huge strikes led to a wave of factory occupations. On the other hand, the breakaway interventionists also took advantage of the situation to mobilise growing support around the patriotic idea of 'national syndicalism'. And with the defeat of the factory occupations, there was the rise of a mass fascist movement, culminating in its seizure of power under Mussolini's leadership in 1922 and the subsequent complete demise of the USI. ${ }^{52}$

If in neutral Spain and colonial Ireland syndicalist movements retained their opposition to war and were beneficiaries of related industrial and political protest, in 
both belligerent France and Italy (two of the most important European countries), syndicalist movements were bedevilled by internal schisms and external repression that undermined the effectiveness of those elements that attempted to hold aloft their internationalism and connect it to industrial protest, although significant gains were nonetheless eventually achieved. By further contrast, in America and Britain, while syndicalists ideologically held firm to an anti-war position, their attempt to translate this into practical activity suffered from some strategic and tactical dilemmas.

\section{America and Britain: dilemma of concretising opposition}

In America, the Industrial Workers of the World (IWW) denounced the war on the basis that it was a purely capitalist struggle for economic leverage that no worker should support. A leaflet prepared by one Wobbly (as IWW members were colloquially known) summarised their attitude sharply: 'General Sherman said "War is Hell!" Don't go to Hell in order to give the capitalists a bigger slice of heaven'. ${ }^{53}$ Neither the outbreak of the war in Europe nor the subsequent intervention of the United States in the spring of 1917 caused the IWW to change their approach. Wobblies advised American workers to remain at home in order to fight the bosses in the only war worthwhile: the class war. Bill Haywood, one of the IWW's most influential leaders, told a protest meeting: 'It is better to be a traitor to your country than to your class. Let the bankers, the rentiers and the dividend-takers go to Sherman's Hell' ${ }^{54}$ And the IWW proposed, in the words of the editor of its paper Solidarity: 'to get on the job of organising the working class to 
take over the industries [...] and to stop all future capitalist aggression that leads to war and other forms of barbarism' ${ }^{55}$

Paradoxically, unlike elsewhere, the outbreak of war in Europe initially provided the occasion and opportunity for the IWW to flourish. Against the background of a tight labour market and an economy in which prices rose more quickly than wages, there was an increase in labour unrest. Even by the time the United States had itself become a belligerent in the war, industrial struggles multiplied, enabling the IWW to expand its membership massively as they combined opposition to the war with a successful organising campaign in the copper mining industry of Montana and Arizona and the lumber industry of the Northwest. For example, in July 1917 25,000 hard-rock miners in Arizona took strike action under IWW leadership, paralysing production of copper for three months. Between 1916 and 1917 IWW membership almost doubled from 40,000 to 75,000 , and by September 1917 they had between $125-150,000$ members. ${ }^{56}$

Yet the war years also exposed the limitations in the IWW's approach to politics and the state. While they were able to play a leading role as strike leaders in some crucial war industries (advising workers to wage the class war at home even while bloody military battles dragged on overseas) their syndicalist rejection of 'political action' meant they did little in practice to politically oppose the war, despite the initially less repressive political context than existed in France or Italy. Thus, they did not campaign to oppose the draft, to explicitly disrupt production in the workplace so as to 
prevent war materials being manufactured or transported, or build a broad-based national anti-war movement. Their ambiguous stance was a reflection of their syndicalist refusal to explicitly link industrial activity with political ideas and organisation. For example, when a member of the IWW wrote to Haywood at the national office asking for advice, first having proposed that the organisation declare a country-wide general strike if Congress declared American participation in the European war, Haywood offered neither support nor counsel. Solidarity's editor opposed strike action against the war:

In case of war we want One Big Union...to come out of the conflict stronger and with more industrial control than previously. Why should we sacrifice working class interests for the sake of a few noisy and impotent parades or anti-war demonstrations? Let us rather get on with the job of organising the working class to take over the industries, war or no war, and stop all future capitalist aggression that leads to war and other forms of barbarism. ${ }^{57}$

When America's entry into the war was finally announced the national IWW office, under Haywood's guidance, demanded the Wobblies play down anti-war propaganda and concentrate upon 'the great work of organisation'. The most militant member of the IWW leadership, Frank Little, advised members to 'stay at home and fight their own battles with their own enemy - the boss'. But Haywood cautioned: 'Keep a cool head; do not talk. A good many feel as you do but the world war is of small importance compared to the great class war...I am at a loss as to define steps to be taken against the war'. ${ }^{58}$ When the government enacted a general conscription law in 
1917 and the Wobblies were faced with the choice of whether or not to register when their draft boards beckoned, Ralph Chaplin used the pages of Solidarity to advise members to mark their claims for exemption 'IWW opposed to war'. But he was overruled by Haywood who stressed it was a matter of individual conscience and choice. 'The fight of the IWW is one of the economic field', Haywood said, 'and it is not for me, a man who could not be drafted for war, to tell others that they should go to war, or tell them they should not go to war'. ${ }^{59}$ In the event, roughly 95 per cent of eligible Wobblies registered with their draft boards and most of those served when called. ${ }^{60}$

The IWW was committed to continuing the class struggle as the war progressed, quite unlike the conservative American Federation of Labour (AFL) who collaborated with the government. Yet they opposed actively taking up the political issue of the war for fear of losing support amongst workers and providing the government with the pretext to use the war emergency to repress their organisation. Paradoxically, however much IWW-influenced strikes sought conventional labour goals the American state interpreted them as direct challenges to the war effort and the legitimacy of federal authority. And with the IWW refusing to renounce its commitment to revolution, the ruling class became increasingly alarmed by their successes on the industrial front and began to whip up huge anti-IWW hysteria as the US prepared to enter the war. The Wobblies were branded 'German spies' and became a target for 'patriotic' violence by local vigilantes, leading to the murder of IWW organisers Frank Little and Wesley Everett. Nonetheless, strikes continued and a broad-based anti-war movement 
subsequently developed which provided the opportunity to link workers' economic grievances with political opposition to the war. Instead the IWW chose to ignore this 'political' anti-war movement, even though, ironically, the reformist-led Socialist Party began to grow in membership by adopting a formal anti-war stance and attracting to its revolutionary wing a new layer of working class activists prepared to campaign in opposition to the war. The IWW's strategy made the government's task of isolating it easier than might have been the case and the organisation suffered heavy state repression it was ill-prepared to survive.

Individual states used the excuse of the war to pass criminal syndicalism laws making it illegal to advocate the overthrow of the state or the seizure of property, and in September 1917 the federal government raided the union's national, regional and state headquarters, arrested over a hundred of the Wobbly leaders and put them on a show trial for violating the wartime sedition and espionage laws, sentencing many of them, including Haywood, to long prison terms. The IWW never really recovered from these attacks and within two years had effectively been destroyed, despite the dramatic increase in union militancy across the country that occurred in the initial post-war period. ${ }^{61}$

In Britain, the organised revolutionary syndicalist movement around Tom Mann's Industrial Syndicalist Education League (ISEL) had already splintered and disintegrated over organisational disputes by the outbreak of the war, although a number of 
individuals remained in prominent positions inside the trade union movement. ${ }^{62}$ With both the Labour Party and trade union leaders seeking to actively encourage collaboration with the state to suspend strikes in an 'industrial truce', Tom Mann's articles in the Daily Herald provided powerful anti-war statements, and there is no evidence of any British syndicalists going over to the pro-war side. But if they did not support the war, neither did they play a distinctive role in explicitly campaigning to oppose it; in fact Mann attempted to play the role of a 'responsible patriot' ${ }^{63}$ (concerned to defend the interests of labour, but also wanting to see Britain win the war so as to prevent the ruling class of Germany gaining ascendancy) calling for peace by negotiations. $^{64}$

Following an initial lull in workers' struggle, as the war progressed militancy in the munitions factories constituted a major problem for the British government, with a powerful engineering Shop Stewards' and Workers' Committee Movement led by a number of syndicalist-influenced revolutionaries, such as Willie Gallacher, Jack Tanner and J.T. Murphy, spearheading resistance to employers and the government. The shop stewards' leaders adopted a position of opposition to the imperialist war and were committed to the overthrow of the state that prosecuted it. In the process, they led unofficial and illegal rank-and-file strikes that threatened to disrupt the flow of arms, irrespective of government attacks and the pro-war policies of the trade union and Labour Party leaders. For example, in 1916 they led a successful strike of 12,000 Sheffield workers to prevent the conscription of an engineer in breach of the 
government's pledge to exempt those employed on munitions work, and in May 1917 led a national strike by 200,000 engineers against an attempt by the government to extend 'dilution' (the substitution of less skilled for skilled labour). A network of Workers' Committees, representative of workshop organisation and committed to the revolutionary goals of workers' control of production and abolition of capitalism, were established across the country.

At the same time, as in America, the shop stewards' leaders refused to agitate politically against the war (albeit from a minority position). Instead they insisted the issue was beyond the bounds of the Workers' Committees' and that they should limit themselves to immediate shopfloor concerns related to wages and conditions. They adopted such a stance in the syndicalist belief that maximum unity to win militant action on such industrial issues was more important than the broader more hotly disputed political questions, including the war, which threatened to puncture such unity. ${ }^{65}$ It was an approach highlighted in sharp relief by the publication of J.T. Murphy's pamphlet The Workers' Committee, the chief theoretical statement to emerge from the National Administrative Council of the shop stewards' movement. 150,000 copies of the document were sold, an indication of its widespread influence.

Significantly, despite being written in 1917 the pamphlet made absolutely no mention of the war and the political issues it raised. Instead, it reduced the immense 
economic and political problems that lay behind the growth of the Workers'

Committees to the level of industrial organisation. ${ }^{66}$ Even those shop stewards' leaders who were members of revolutionary socialist parties, such as the British Socialist Party and the Socialist Labour Party, acted no differently. No doubt Murphy, Gallacher and others denounced the war at BSP and SLP meetings, but they made no attempt to propagate their views publicly amongst the rank-and-file in the factories for fear of losing support, remaining content to merely defend workers against the threats to their organisation brought about by the war. In effect, they wore two hats, one reserved for their party activities, the other, a shop steward's hat, to be worn as a representative of the rank-and-file, many of whom were, initially at least, pro-war. ${ }^{67}$

Yet in many respects every issue workers faced and every industrial dispute over wages and conditions of work was inherently profoundly political, since they all arose directly as a result of the government's determination to win outright victory in the war. As a consequence, the extreme political circumstances of the war and the perceived failure of the labour leaders to defend workers in the face of an all-out attack by employers and the state, opened up possibilities for a class-wide agitation for militant trade unionism that fused immediate economic issues with a political challenge to the employers and the state over the war. In the event, as Murphy and others were later to acknowledge, relying simply on the industrial struggle had the effect of handing the political initiative to the 'patriotic' reformist labour leadership, isolating the movement to the engineering industry and limiting its overall potential. ${ }^{68}$ Although the end of the 
war initially saw widespread industrial militancy, with the rundown of the munitions industry and subsequent heavy unemployment, it also brought a rapid demise of the shop stewards' movement.

So to recap, in both America and Britain, although they gained significant influence and were able to lead important workplace struggles, the syndicalists' tradition of treating politics as something external to the workplace and shopfloor unrest as simply an economic issue effectively undermined the impact of their internationalist opposition to the war.

\section{Assessment}

In conclusion, Wayne Thorpe was undoubtedly justified in emphasising the distinctive contribution to the fight against the First World War made by revolutionary syndicalists in a number of European countries. Unlike the vast bulk of the leaders of the mainstream socialist and trade union movement, syndicalists often adopted a determined and internationalist stance. No doubt their commitment to working class self-emancipation, to revolutionary industrial struggle from below to overthrow capitalism rather than reform of the system from above, helps explain the difference in approach to the war. Such an internationalist stance contributed, along with the revival of workers' combativity towards the end of the war period, to the growth in 
membership experienced by different syndicalist organisations, which enabled them to influence the ideas and activity of significant minority sections of the working class.

But the evidence presented in this disaggregated study of different national contexts also underlines some of the limitations and dilemmas that were involved in the syndicalists' approach. These included the collapse into 'defencism' of their respective national states amongst significant elements of two of the largest syndicalist movements in Europe, and the broader strategic and tactical limits of the syndicalists' antipathy to political parties and subordination of the political question of the war to the industrial struggle manifest to a greater or lesser degree in different national contexts. Variation in syndicalist response from one movement to another appears to have been influenced by a variety of factors, including particular countries' engagement with the war, the economic and political conditions in each country, and the size of respective syndicalist organisation, with the absorption of reformist elements within the body of the CGT itself, rather than in a rival trade union centre (as elsewhere), a crucial factor in explaining why French syndicalism was so different.

Of course, the limitations outlined above by no means undermine Thorpe's substantive attempt to rescue the syndicalist contribution from those historians who have overlooked, downplayed or condescendingly dismissed it. But they do qualify the picture that he presented. 


\section{Notes}

${ }^{1}$ Peterson, 'One Big Union', 64-6.

${ }^{2}$ Darlington, From Syndicalism to Communism.

${ }^{3}$ For a comparative analysis of the development and influence of anarchist ideology and organisation in syndicalist movements in France, Italy and Spain, see Darlington, 2009. It should be noted that any one of the supposedly more nationally-specific terms, such as 'anarcho-syndicalism', are themselves somewhat problematic given the changes in leadership and direction that tended to occur over time within individual movements. Although the term 'anarcho-syndicalism' is often used to describe the Spanish CGT, in reality a 'pure syndicalist' period extended from its foundation in 1907 to its 1919 national congress; it was only then that the anarcho-syndicalists briefly took over, before the CNT's banning in 1924 when it fell into the hands of more moderate syndicalists, before anarchists eventually came back to the fore with the advent of the Second Republic and the subsequent Civil War. Thus any attempt to substitute the broad term 'syndicalism' with a more defined term, by no means necessarily clarifies our understanding (at least outside of context and time period) and can, in fact, sometimes be misleading.

${ }^{4}$ Thorpe, 'European Syndicalists and War'. For other similar comparative overviews see Thorpe's 'El Ferrol, Rio de Janeiro, Zimmerwald, and Beyond' and 'Challenging the 
Cultural Legitimation of War', as well as 'Keeping the Faith' for a specific exploration of the German syndicalist experience during the war.

${ }^{5}$ Quoted in Novak et al, The First Three Internationals, 68.

${ }^{6}$ Anarcho-Syndicalism 101 class struggle online:

http://anarchosyndicalism.net/index.php

libcom.org

http://libcom.org/

Anarchosyndicalist Review

http://www.syndicalist.org/

${ }^{7}$ History of Anarcho-Syndicalism.

${ }^{8}$ Stone, Europe Transformed; Lozovsky, Marx and the Trade Unions.

${ }^{9}$ An earlier, shorter and less developed, version of this article was first published in the Belgian journal Revu Belge De Philologie Et D'Histoire (2006). The study was based on a much wider research project published in a full-length book entitled Syndicalism and the Transition to Communism: An International Comparative Analysis (2008) and was financially assisted by grants from the Lipman-Miliband Trust and the British Academy (SG-34667).

${ }^{10}$ Meaker, The Revolutionary Left in Spain, 21.

${ }^{11}$ Solidaridad Obrera, 25, November 1914. 
12 Solidaridad Obrera, 11 May 1917.

${ }^{13}$ Meaker, op. cit, 28.

${ }^{14}$ Quoted in Bar, Syndicalism and Revolution in Spain.

${ }^{15}$ Thorpe, 'European Syndicalists and War', 5; 10-11.

${ }^{16}$ Bar, 'The CNT: The Glory and Tragedy of Spanish Anarchosyndicalism', 123; 125.

17 Jim Larkin, Irish Worker, 8 August 1914.

${ }^{18}$ Jim Larkin, Irish Worker, 15 August 1914.

${ }^{19}$ Larkin, James Larkin, 163.

${ }^{20}$ Jim Larkin, Irish Worker, 27 September 1914.

${ }^{21}$ Greaves, The Life and Times of James Connolly, 378.

${ }^{22}$ Forward, 15 August 1914. 
${ }^{23}$ O’Connor, A Labour History of Ireland, 91.

${ }^{24}$ Newsinger, Rebel City.

${ }^{25}$ Irish Worker, 8 August 1914.

${ }^{26}$ See Bambery, Ireland's Permanent Revolution, Allen, The Politics of James Connolly and Anderson, James Connolly and the Irish Left.

${ }^{27}$ Lenin, British Labour and British Imperialism, 166.

${ }^{28}$ See O'Connor, Syndicalism in Ireland and A Labour History of Ireland; also useful is Kostick, Revolution in Ireland.

${ }^{29}$ XVI Congrès national corporatif (X de la CGT) et 3 Conférence des Bourses du Travail ou Unions des Syndicates, tenus á Marseille du 5 au 12 octobre 1908. Compte rendu sténographique des travaux (Marseille, 1909).

${ }^{30}$ Graveraux, Les discussions sur le patriotisme et le militariam, 108; 209-10.

${ }^{31}$ Becker, Le Carnet B, 57. 
${ }^{32}$ Magraw, 'Socialism, Syndicalism and French Labour', 96.

${ }^{33}$ Ridley, Revolutionary Syndicalism in France, 139; 184-5.

${ }^{34}$ Cited in Jennings, Syndicalism in France, 162.

${ }^{35}$ Horne, 'The State and the Challenge for Labour in France, 239-61.

${ }^{36}$ Magraw, A History of the French Working Class, Vol. 2, 155.

${ }^{37}$ Mitchell, 'French Syndicalism: An Experiment in Practical Anarchism', 37-39.

38 Jennings, Syndicalism in France, 165.

${ }^{39}$ Magraw, 'Paris 1917-20', 128-34.

${ }^{40}$ Internazionale, 1, 8 August 1914.

41 Bertrand, 'Revolutionary Syndicalism in Italy 1912-1922', 52-7; see also 'Italian Revolutionary Syndicalism and the Crisis of Intervention', 349-67. 
${ }^{42}$ Bertrand, 'Revolutionary Syndicalism in Italy 1912-1922', 125.

${ }^{43}$ L'Internazionale (Parma) 22 August 1914.

${ }^{44}$ L'Internazionale, 19 September 1914.

${ }^{45}$ Revolutionary Syndicalism, 146.

${ }^{46}$ L'Internazionale, 19 September 1914.

${ }^{47}$ L'Internazionale (Parma), 17 October 1914.

${ }^{48}$ Guerra di Classe (Bologna) 22 May 1915.

${ }^{49}$ Bertrand, 'Revolutionary Syndicalism in Italy 1912-1922', 122-23; 184.

${ }^{50}$ Borghi, Mezzo secolo di anarchia, 115.

${ }^{51}$ Guerra di Classe (Bologna) 7 January 1920.

${ }^{52}$ Roberts, The Syndicalist Tradition and Italian Fascism. 
53 Industrial Worker, 11 May 1914; Solidarity, 20 May 1911.

54 Solidarity, 25 April 1914; 23 May 1914.

55 Dubofsky, 'The Rise and Fall of Revolutionary Syndicalism in the United States', 215. See also Dubofsky, We Shall Be All and Foner, History of the Labor Movement in the United States: Vol. 4.

${ }^{56}$ Dubofsky, 'The Rise and Fall of Revolutionary Syndicalism', 214; Foner, The History of the Labor Movement in the United States: Vol. 7.

${ }^{57}$ Solidarity, 17 February 1917.

${ }^{58}$ Letter from Bill Haywood to Frank Little, cited in Renshaw, The Wobblies, 217.

59 William D. Haywood v United States, Supreme Court, October 1920, IV, 12, 611. Haywood could not drafted because he was a diabetic.

${ }^{60}$ Dubofsky, 'Big Bill' Haywood, 100.

${ }^{61}$ Significantly, the position adopted by William Z. Foster of the International Trade Union Education League was not substantially different from the IWW. In the first 
months of the war, Foster inveighed bitterly against the conflict. However in 1916 at an ITUEL conference in Kansas City he argued that the league should not take sides in the European conflict and that American involvement was inevitable. According to Foster, radicals within the unions should ignore the moral issues of the war and focus their main attention on preparing to 'take advantage of war conditions to organise the workers and raise bigger and bigger demands'. See Johanningsmeier, Forging American Communism, 84.

62 Holton, British Syndicalism.

${ }^{63}$ Tsuzuki, Tom Mann, 178.

${ }^{64}$ Letter from Tom Mann to R. S. Ross, 11 April 1915, reprinted in Justice, (12 August 1915); see also Mann's report on Liverpool District, in National Transport Workers' Federation, Report of the Sixth Annual General Council Meeting held in Glasgow, 8-9 June 1916 (London, 1916), 100-1.

${ }^{65}$ Pribicevic, The Shop Stewards' Movement and Workers' Control; Hinton, The First Shop Stewards' Movement.

${ }^{66}$ Murphy, The Workers' Committee; New Horizons, 44. 
${ }^{67}$ Gluckstein, The Western Soviets, 59-89; Cliff and Gluckstein, Marxism and the Trade Union Struggle, 63-69; Darlington, Political Trajectory of J.T. Murphy, 41-46.

${ }^{68}$ Murphy, New Horizons, 146; 159-60; 166; McShane and Smith, No Mean Fighter, 76-8; 86.

\section{References}

Allen, Kieran. The Politics of James Connolly. London: Pluto Press, 1990.

Anderson, William K. James Connolly and the Irish Left. Wiltshire: Irish Academic Press, 1994.

Bambery, Chris. Ireland's Permanent Revolution. London: Bookmarks, 1986.

Bar, Antonio. Syndicalism and Revolution in Spain: The Ideology and Syndical Practice of the CNT in the Period 1915-191. New York: Gordon Press, 1981.

Bar, Antonio. 'The CNT: The Glory and Tragedy of Spanish Anarchosyndicalism', in Marcel van der Linden and Wayne Thorpe (eds.) Revolutionary Syndicalism: An International Perspective Aldershot: Scholar Press, 1990. 
Becker, Jean-Jacques. Le Carnet B: Les pouvoirs publics et l'antimilitarisme avant la guerre de 1914. Paris: Editions Klincksieck, 1973.

Bertrand, Charles L. 'Revolutionary Syndicalism in Italy 1912-1922', PhD, University of Wisconsin (1970).

Bertrand, Charles L. 'Italian Revolutionary Syndicalism and the Crisis of Intervention: August-December 1914', Canadian Journal of History, 10, 3 (1975): 349-67.

Bertrand, Charles L. 'Revolutionary Syndicalism in Italy', in Marcel van der Linden and Wayne Thorpe (eds.) Revolutionary Syndicalism: An International Perspective Aldershot: Scholar Press, 1990.

Borghi, Armando. Mezzo secolo di anarchia, 1898-1945. Naples, 1954.

Cliff, Tony and Donny Gluckstein, Marxism and the Trade Union Struggle: The General Strike of 1926. London: Bookmarks, 1986.

Darlington, Ralph. The Political Trajectory of J.T. Murphy. Liverpool University Press: 1998. 
Darlington, Ralph. 'Revolutionary Syndicalist Opposition to the First World War: A Comparative Reassessment', Revu Belge De Philologie Et D'Histoire, 12, 4 (2006): 9831003.

Darlington, Ralph. 'Syndicalism and the Influence of Anarchism in France, Italy and Spain', Anarchist Studies, 17:2 (2009): 29-54.

Darlington, Ralph. Syndicalism and the Transition to Communism: An International Comparative Analysis. Aldershot: Ashgate, 2008.

Dubofsky, Melvyn. We Shall Be All: A History of the Industrial Workers if the World. Chicago: Quadrangle Books, 1969.

Dubofsky, Melvyn. 'Big Bill' Haywood. Manchester: Manchester University Press, 1987.

Dubofsky, Melvyn. 'The Rise and Fall of Revolutionary Syndicalism in the United States', in Marcel van der Linden and Wayne Thorpe (eds.) Revolutionary Syndicalism: An International Perspective Aldershot: Scholar Press, 1990.

Foner, Philip S. History of the Labor Movement in the United States: Vol. 4: The Industrial Workers of the World 1905-191. New York: International Publishers, 1965. 
Foner, Philip S. The History of the Labor Movement in the United States: Vol. 7: Labor and World War I: 1914-1918. New York: International Publishers, 1987.

Gluckstein, Donny. The Western Soviets. London: Bookmarks, 1985.

Graveraux, L. Les discussions sur le patriotisme et le militariam dans les congrès socialistes. Paris 1913.

Greaves, C. Desmond. The Life and Times of James Connolly. London: Lawrence and Wishart, 1961.

Hinton, James. The First Shop Stewards' Movement. London: Allen and Unwin, 1973.

History of Anarcho-Syndicalism, Unit 13: 'Going Global - International Organisation, 1872-1922' (second edition, 2001), www.selfed.org.uk

Holton, Bob. British Syndicalism 1900-1914. London: Pluto Press, 1976.

Horne, John. 'The State and the Challenge for Labour in France 1917-20', in Chris Wrigley (ed.) Challenges of Labour: Central and Western Europe 1917-2. London: Routledge, 1993. 
Jennings, Jeremy. Syndicalism in France: A Study of Ideas. London: Macmillan, 1990.

Johanningsmeier, Edward P. Forging American Communism: The Life of William Z. Foster. Princeton University Press, 1994.

Kostick, Conor. Revolution in Ireland: Popular Militancy 1917 to 1923. London: Pluto Press, 1996.

Larkin, Emmet. James Larkin: Irish Labour Leader 1876-1947. London: New English Library, 1968.

Lenin, Vladimir. British Labour and British Imperialism. London: Lawrence and Wishart, 1969.

Lozovsky, A. Marx and the Trade Unions, London: Martin Lawrence, 1935.

Magraw, Roger. 'Socialism, Syndicalism and French Labour Before 1914', in Dick Geary (ed.) Labour and Socialist Movements in Europe Before 1914. Oxford, Berg, 1989.

Magraw, Roger. A History of the French Working Class, Vol. 2: Workers and the Bourgeois Republic. Oxford: Blackwell, 1992. 
Magraw, Roger. 'Paris 1917-20: Labour Protest and Popular Politics', in C. Wrigley (ed.), Challenges of Labour: Central and Western Europe, 1917-2. London: Routledge, 1993.

McShane Harry and Joan Smith, No Mean Fighter. London: Pluto Press, 1978.

Meaker, Gerald H. The Revolutionary Left in Spain, 1914-1923. Stanford University Press, 1974.

Mitchell, Barbara. 'French Syndicalism: An Experiment in Practical Anarchism', in Marcel van der Linden and Wayne Thorpe (eds.) Revolutionary Syndicalism: An International Perspective Aldershot: Scholar Press, 1990.

Murphy, J. T. The Workers' Committee: An Outline of its Principles and Structure. Sheffield Workers' Committee, 1917.

Murphy, J. T. New Horizons. London: John Lane/The Bodley Head, 1941.

Newsinger, John. Rebel City: Larkin, Connolly and the Dublin Labour Movement. London: Merlin Press, 2004.

Novak, George, Dave Frankel and Fred Feldman, The First Three Internationals: Their History and Lessons. New York: Pathfinder Press. 1974. 
O’Connor, Emmet. Syndicalism in Ireland: Cork University Press, 1988.

O'Connor, Emmet. A Labour History of Ireland 1824-1960. Dublin: Gill and Macmillan, 1992.

Peterson, Larry, 'The One Big Union in International Perspective: Revolutionary Industrial Unionism 1900-1925', in J. E. Cronin and C. Sirianni (eds.), Work, Community and Power: The Experience of Labour in Europe and America 1900-1925, Philadelphia, 1983.

Pribicevic, Branko. The Shop Stewards' Movement and Workers' Control. Oxford: Blackwell, 1959.

Renshaw, Patrick. The Wobblies: The Story of Syndicalism in the United States. London: Eyre and Spottiswoode, 1967.

Ridley, Frederick F. Revolutionary Syndicalism in France: The Direct Action of its Time. Cambridge University Press, 1970.

Roberts, David D. The Syndicalist Tradition and Italian Fascism. Manchester University Press, 1979. 
Stone, Norman. Europe Transformed 1879-1919 (second ed.). Blackwell, 1999.

Thorpe, Wayne. 'The Workers Themselves': Revolutionary Syndicalism and International Labour, 1913-1923. Amsterdam: Kluwer Academic Publishers. 1989.

Thorpe, Wayne. 'Keeping the Faith: The German Syndicalists in the First World War', Central European History, 33, 2 (2000): 195-216.

Thorpe, Wayne. "The European Syndicalists and War, 1914-1918", Contemporary European History, 10, 1 (2001): 1-24.

Thorpe, Wayne. 'El Ferrol, Rio de Janeiro, Zimmerwald, and Beyond: Syndicalist Internationalism, 1914-1918' in Revu Belge De Philologie Et D'Histoire, 12, 4 (2006): 1005-23.

Thorpe, Wayne. 'Keeping the Faith: The German Syndicalists in the First World War', Central European History, 33 (2000): 195-216.

Thorpe, Wayne. 'Challenging the Cultural Legitimation of War: International Syndicalists in Europe 1914-18', Socialist History, 37 (2010): 23-46. 
Tsuzuki, Chuschichi. Tom Mann 1856-1941: The Challenges of Labour. Oxford, Clarendon Press, 1991. 